\title{
THD performance of single phase five level inverter using proportional resonant and harmonic compensators current controller
}

\author{
Abdullah Mohamed, Suriana Salimin \\ Green and Sustainable Energy Focus Group (GSEnergy), Faculty of Electrical and Electronic Engineering, Universiti \\ Tun Hussein Onn Malaysia (UTHM), Malaysia
}

\begin{tabular}{l} 
Article Info \\
\hline Article history: \\
Received Jan 10, 2020 \\
Revised Mar 12, 2020 \\
Accepted Apr 3, 2020 \\
\hline
\end{tabular}

Keywords:

Five level inverter Harmonic compensators Proportional resonant Total harmonic distortion

\begin{abstract}
This paper observe the total harmonic distortion (THD) performance of single phase five level inverter using proportional resonant (PR) and harmonic compensators current controller. The THD when adding PR current controller was $1.6 \%$ at first. After more functions were added to the PR current controller to reduce the THD at the 3rd, 5th and 7th harmonic orders, the THD of the 3rd harmonic order was reduced from $0.45 \%$ to $0.1 \%$ while the 5 th and 7 th harmonic orders were reduced from $0.6 \%$ and $0.43 \%$ to $0.25 \%$ and $0.4 \%$ respectively. The development and simulation is performed using Matlab/Simulink. The simulation result is performed by using Fast Fourier Transform analysis (FFT) for the harmonics captured.
\end{abstract}

This is an open access article under the CC BY-SA license.

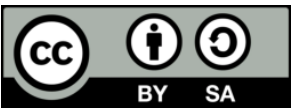

\section{Corresponding Author:}

Suriana Salimin,

Green and Sustainable Energy Focus Group (GSEnergy), Faculty of Electrical and Electronic Engineering, Universiti Tun Hussein Onn Malaysia, 86400 Parit Raja, Batu Pahat, Johor.

Email: suriana@uthm.edu.my

\section{INTRODUCTION}

High and medium power voltage applications are now demanding in using cascade multilevel inverter (CMLI) structure. When compared to the lower level inverters, it is due to to its reduced harmonics, improved efficiency and low voltage stress [1-4]. For instance of current multilevel converter in used are the diode clamped, cascaded $\mathrm{H}$-bridge inverters (CHBI) as well as flying capacitors. When several H-bridge inverters with each H-bridge has its own DC source or a single DC source and capacitors based DC sources are connected in series, it is then called as s cascaded multilevel inverter. If the cascaded multilevel inverter has $\mathrm{k}$ DC sources and number of $\mathrm{H}$ - bridge cells, it provides $(2 \mathrm{k}+1)$ levels to synthesize the AC output waveform. Following that, to form a five-level inverter (FLI), two DC sources and two cascaded $\mathrm{H}$-bridge cells will be required [5-11].

Researchers have made several attempts to combine multilevel inverter (MLI) with a number of $\mathrm{H}$ bridge cells with the $(2 k+1)$ levels method. Bigger number of diodes and auxiliary switches are normally combined in the power circuit to develop a high level MLI. In [7], two H -bridge cells were arranged to make an eleven-level of cascaded $\mathrm{H}$-bridge MLI. For this, four additional switches and eight additional diodes were used. The control circuit and design process are expected to be complex. It is also mentioned in [8] that all FLIs that has been developed present more than one diode and auxiliary switch with an extra control circuits. As an example, there are structures with two auxiliary switches and two anti- bidirectional diodes, 
with two other diodes through which the capacitors are discharged plus two DC voltage sources are combined together in addition to the single $\mathrm{k}$ cell structure [6-10]. In other structure, one additional switch, four diodes and either two DC sources or two capacitors across a boost converter are in used to realize the FLIs output voltages [8-15]. Because of the structures in the control circuit of five level inverters are complexed, few authors have presented on the control scheme [16-24], mostly on H-bridge inverters and FLI. This paper discussed on an improved control scheme in single phase FLI using proportional resonant (PR) together with harmonic compensators current controller, where performance on the total harmonic distortion (THD) is also highlighted.

\section{RESEARCH METHOD}

\subsection{System design}

Overall block diagram of 5-level inverter system using the PR current controller is shown in Figure 1. The system is modelled and designed with main 5 parts which are divided into DC source, single phase 5-level inverter, PWM driver, low pass filter, and current controller. Proper design technique and circuit will be shown in the next few sections.

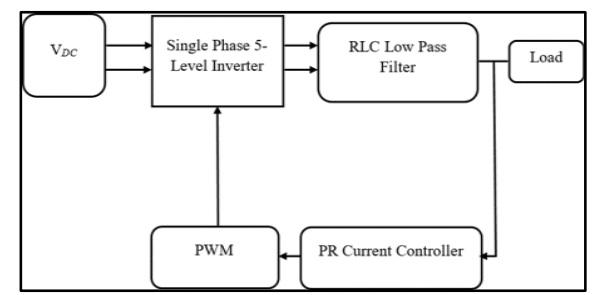

Figure 1. Block diagram of 5-level inverter system with PR current controller

\subsection{Single Phase 5-level inverter with PWM}

The inverter of this power system is fully controlled by eight IGBT/Diodes and it is supplied by 400 Vdc with two DC sources $200 \mathrm{~V}$ each as can be seen in Figure 2.

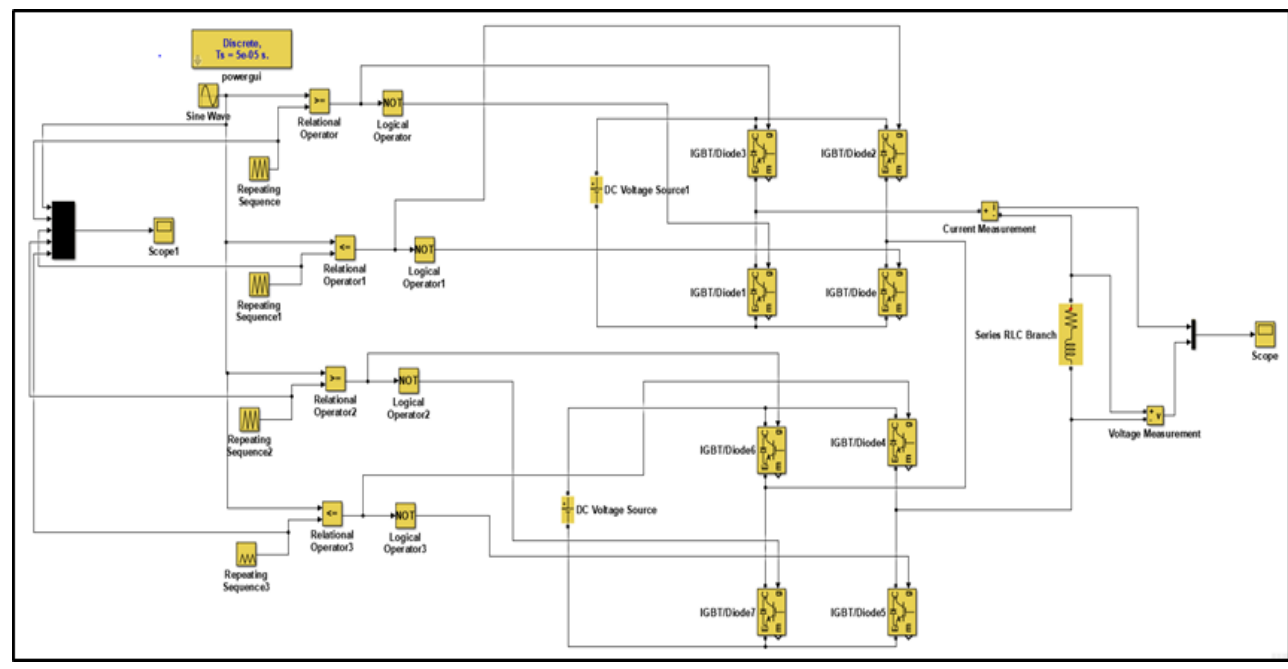

Figure 2. Single phase 5-level inverter circuit

The circuit design followed the H-bridge circuit where the IGBT/Diode is functioned as the switching device which follows the command of PWM waveform. The gates of all IGBT/Diodes are supplied by a PWM generator with $100 \mathrm{~Hz}$ switching frequency. The sine-wave block will generate input sine wave signal to the circuit with frequency $2 * \pi^{*} 50$ and amplitude of 1 . There are two measurement devices in the 
circuit one to measure the current and other to measure the voltage. From the voltage measurement, scope one will show the voltage while from the current measurement, scope two will show the current waveform.

\subsection{RLC low pass filter}

The RLC Low Pass Filter is chosen for this design because there is the function of inductor and capacitor to turn the square waveform from the inverter into sinusoidal waveform for the current because of the behavior of charging and discharging energy. Cut-off frequency, $f_{c}$ is given as formula.

$$
f_{c}=\frac{1}{2 \pi \sqrt{L_{F} C_{F}}}
$$

Where $L_{F}$ is the filter inductance and $C_{F}$ is the filter capacitance. For the initial inductance selection, it can be calculated from formula.

$$
L_{F}=\frac{1}{4 f_{s w} \triangle I_{p p}}
$$

The ripple factor, $\triangle I_{p p}$ chosen for current is $5 \%$ and the cut-off frequency is $1 \mathrm{kHz}$. The inductance for this low pass filter after tuning is $9 \mu \mathrm{H}$. After that, the value of capacitor is calculated using cut-off frequency formula. After tuning, the value of capacitor is $9 \mathrm{pF}$.

\subsection{PR current controller}

Figure 3 shows the PR current control strategy. Ii is the inverter output current, $\mathrm{I}^{*}$ is the inverter current reference and $\mathrm{Ui}^{*}$ is the inverter voltage reference.

The PR current controller $G_{P R}(s)$ is represented by

$$
G_{P R}(s)=K_{P}+K_{r} \frac{s}{2+w_{o}^{2}}
$$

Where $K_{P}$ is the proportional gain whilst $K_{r}$ is resonant gain. $\omega_{o}$ is the resonant frequency at fundamental which is at $50 \mathrm{~Hz}$.

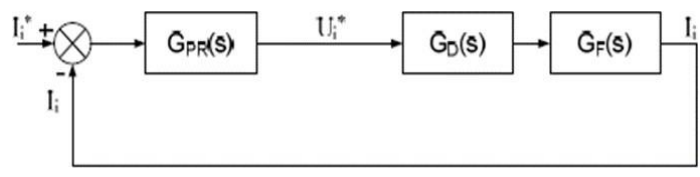

Figure 3. The PR current control [22]

\subsection{PR Control with Harmonic Compensators}

Figure 4 shows the PR current control with additionnal harmonic compensation strategy.

The harmonic compensator $G_{H}(s)$ is represented by:

$$
G_{H}(s)=\sum_{h=3,5,7, \ldots . .} K_{r h} \frac{s}{s^{2}+\left(h w_{o}\right)^{2}}
$$

Here, $K_{r h}$ is the resonant term at the particular harmonic and $h w_{o}$ is the resonant frequency of the particular harmonic. The harmonic compensator for each harmonic frequency is added to the fundamental frequency PR controller to form the complete current controller, as illustrated in Figure 4.

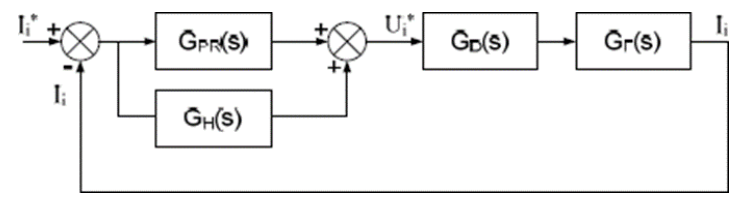

Figure 4. The PR current control with harmonic compensators [22] 


\section{RESULTS AND DISCUSSION}

For this work, the simulation is done by using Matlab/Simulink software. The structure consist of 8 IGBT/Diodes, 2 DC sources, low pass filter (PF), current and voltage measurement, SPWM, and PR current controller. The goal of this design is to design a 5-level inverter with low THD by using PR current controller and reduce the 3th, 5th, and 7th harmonics. The design has three parts, first part is to design single phase 5level inverter and the second part is to add PR current controller to the first design to reduce the THD level. Then FFT analysis will be used to monitor the THD changes that will happen. Thirdly, more functions were added to the PR current controller to reduce the 3 th, 5th, and 7 th harmonics.

\subsection{Simulation of single phase 5-Level inverter}

The design process simply started by designing single phase 5-level inverter without PR current controller to see the THD level of the inverter without the controller so that it will be clear the difference of PR current controller to the inverter in terms of reducing the THD level. Figure 5 shows the simulation result. The switching frequency is $100 \mathrm{~Hz}$ and the magnitude of the voltage is $400 \mathrm{~V}$ as expected.

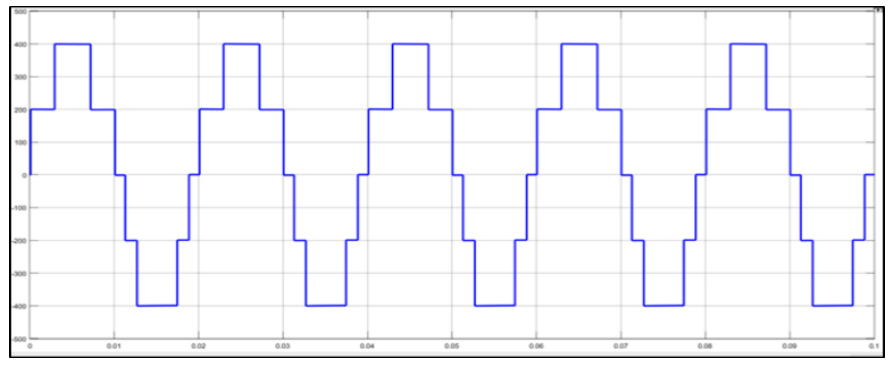

Figure 5. The voltage output of single phase 5-level inverter

\subsection{Single Phase 5-Level Inverter with PR current controller}

The second phase of the design process is to add PR current controller and low pass filter to the single phase 5-level inverter circuit. The output from the current measurement will be the input of the current controller while the output of the current controller will be the input of the inverter circuit. It is illustrated as in Figure 6.

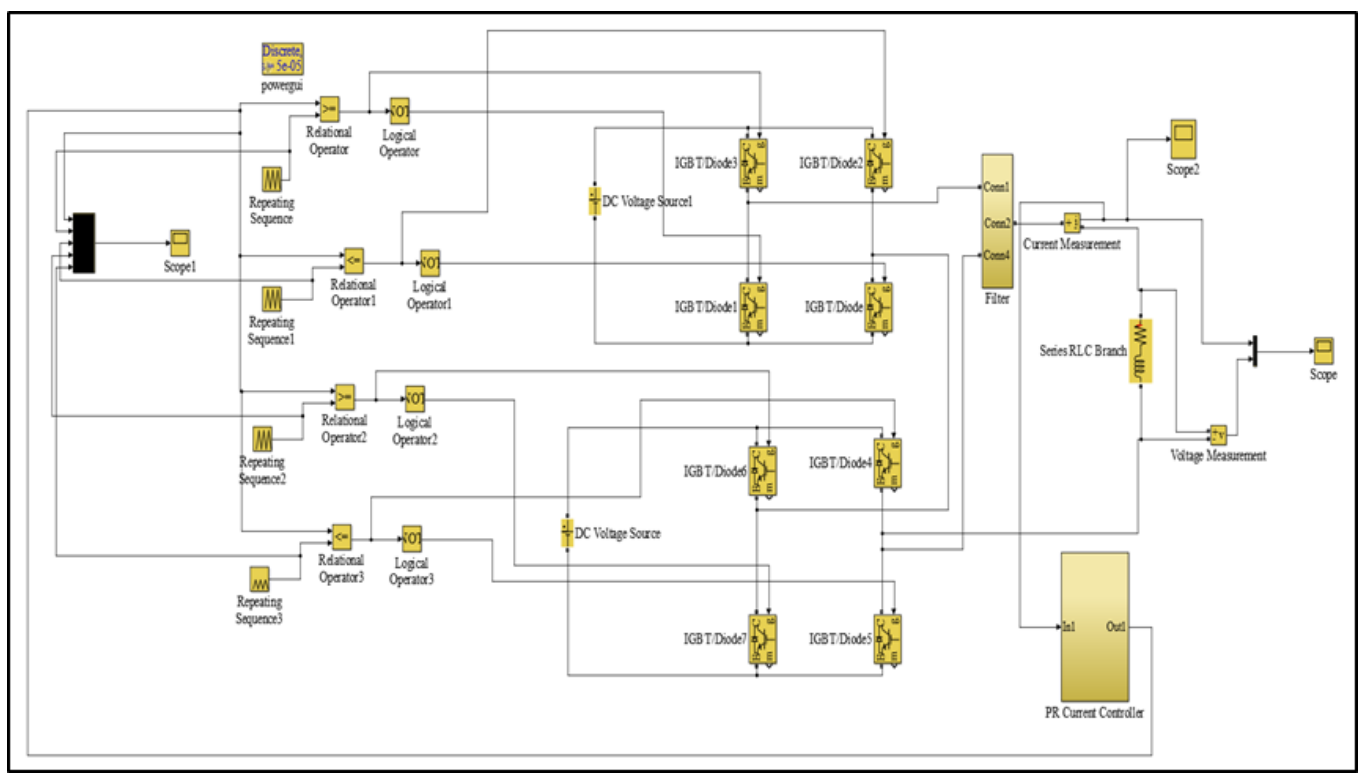

Figure 6. Single phase 5-level inverter with PR current controller circuit 
Inside the PR current controller block, the circuit is shown in Figure 7. The controller has sine wave as reference input with $60 \mathrm{~A}$ reference current and frequency of $2 * \pi * 50$. The input node (in 1 ) is where controller will receive the input current from inverter while the output node (out 1) is the controller output which will go back to the inverter as input in a close loop.

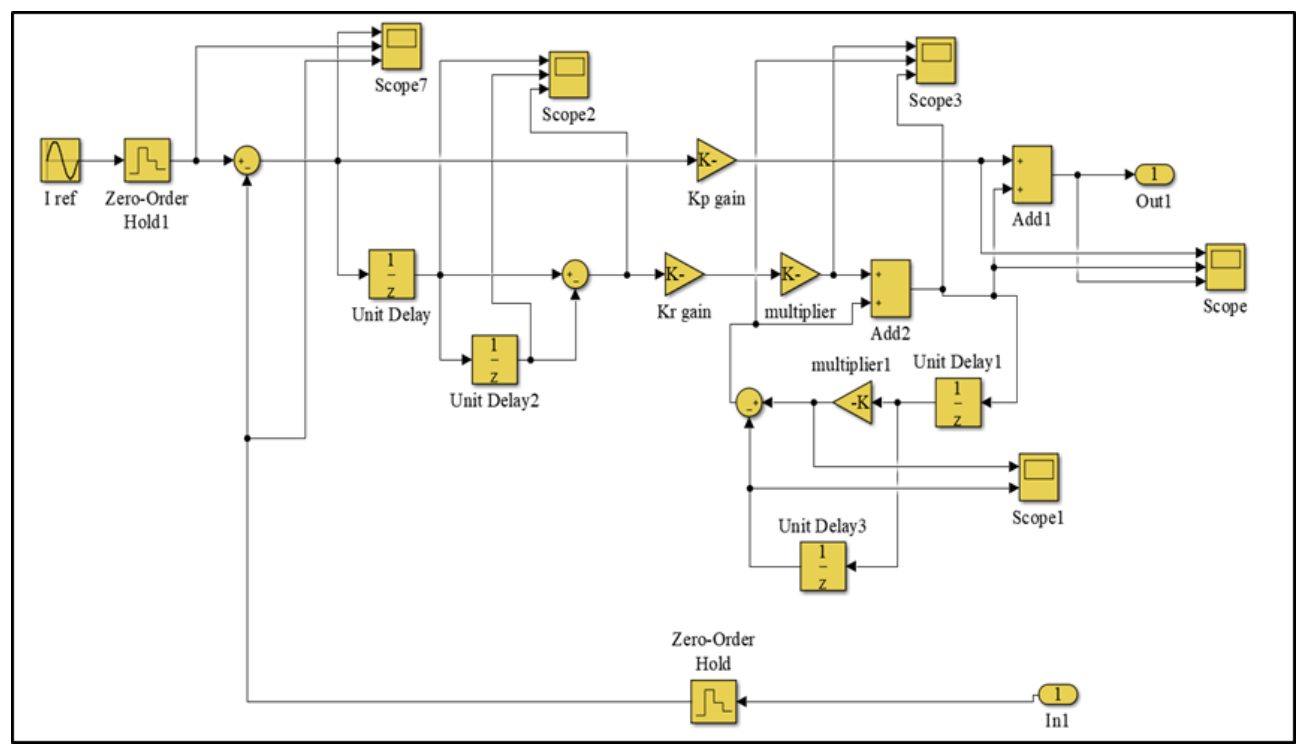

Figure 7. PR current controller circuit.

\subsection{FFT analysis of single phase 5-level inverter with PR current controller}

After adding PR current controller, the FFT analysis tool shows that the THD is $1.6 \%$ with $\mathrm{Kp}=$ 0.38 , and $\mathrm{Kr}=1600$ at fundamental frequency $(50 \mathrm{~Hz})$ which is less than the $5 \%$ [25] as shown Figure 8.

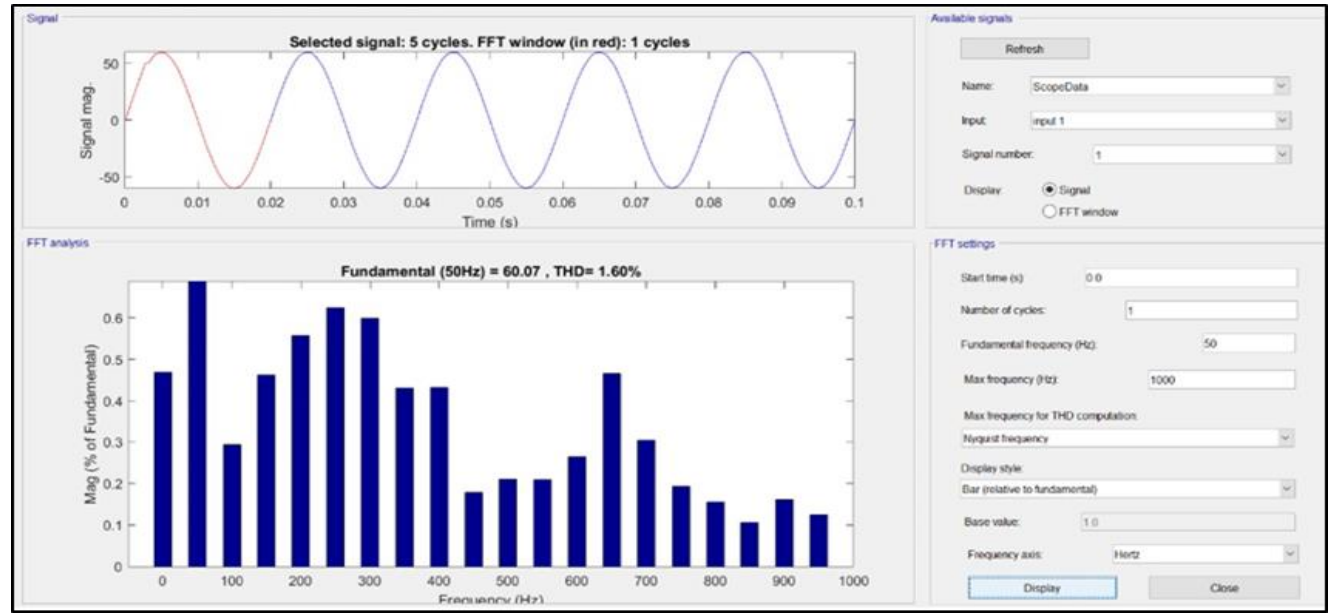

Figure 8. FFT analysis of single phase 5-level inverter with PR current controller

\subsection{FFT analysis of single phase 5-level inverter with $P R$ current controller and harmonic compensator}

It can be seen in Figure 8 above, the THD value of 3rd, 5th, and 7th harmonic orders are high. In order to reduce it, adjustments were made to the PR current controller circuit by adding three parallel set of circuit each set consists of $\mathrm{Kr}$ gain, two multipliers, adder, and 4-unit delay. Each added circuit is focusing on reducing the problematic 3rd, 5th and 7th harmonics. After the simulation the THD of 3rd, 5th and 7th harmonics have decreased as shown in the FFT analysis in Figure 9. The comparison of THD value of 3rd, 5 th and 7th harmonics before and after reduction is also shown in Table 1. 


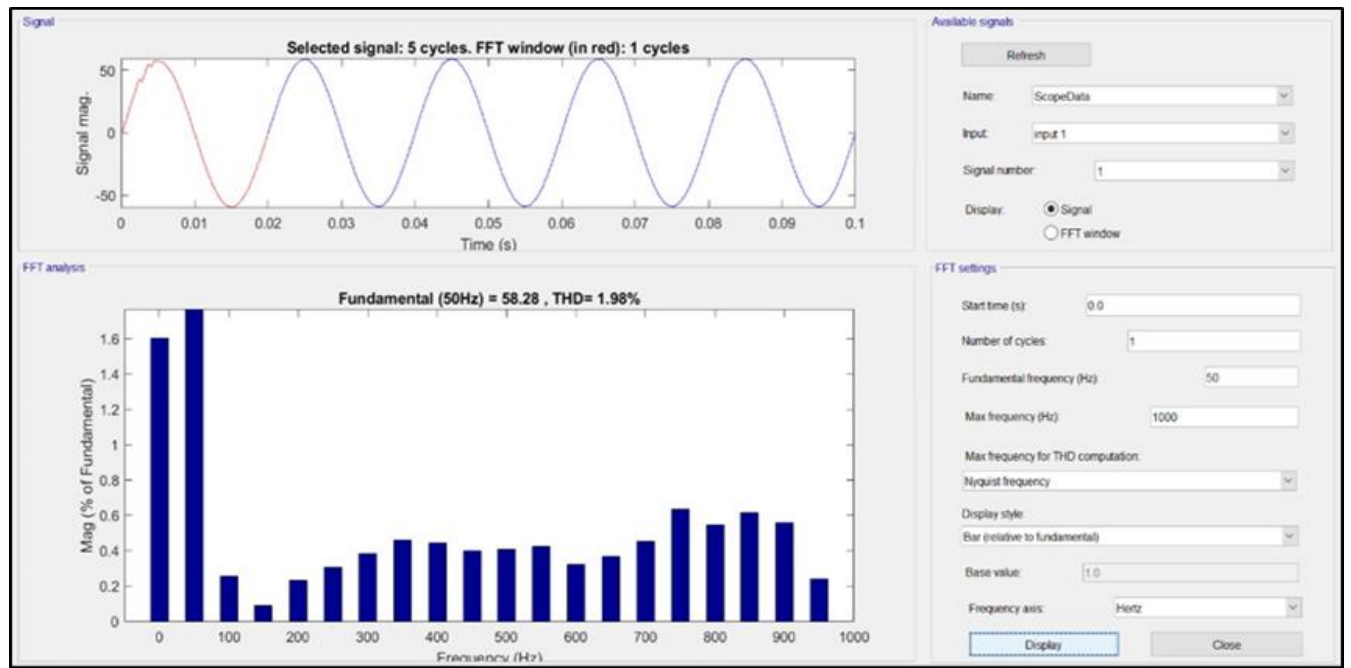

Figure 9. FFT analysis of single phase 5-level inverter with PR current controller and harmonic compensator.

Table 1. Comparison of THD value of $3^{\text {th }}$, 5th, and $7^{\text {th }}$ harmonics before and after reduction

\begin{tabular}{cccc}
\hline & Harmonic order & $\begin{array}{c}\text { Magnitude }(\% \text { of fundamental) } \\
\text { before reduction }\end{array}$ & $\begin{array}{c}\text { Magnitude (\% of fundamental) } \\
\text { after reduction }\end{array}$ \\
\hline 0 & 0 & 0.45 & 1.62 \\
50 & 1 & 0.7 & 1.85 \\
100 & 2 & 0.25 & 0.2 \\
150 & 3 & 0.45 & 0.1 \\
200 & 4 & 0.55 & 0.19 \\
250 & 5 & 0.6 & 0.25 \\
300 & 6 & 0.58 & 0.27 \\
350 & 7 & 0.43 & 0.4 \\
400 & 8 & 0.43 & 0.38 \\
\hline
\end{tabular}

From the table, the 3 rd order improved by $77.78 \%$ while the 5 th and 7 th harmonics orders improved by $58.33 \%$ and $6.98 \%$ respectively.

\section{CONCLUSION}

Design and simulation result of single phase five-level inverter with PR current controller and harmonic compensator has been discussed in this paper. This design involves three major steps. Firstly, single phase five-level inverter was designed with $100 \mathrm{~Hz}$ switching frequency and 400v of DC source. The five-level voltage output waveform was produced. Secondly, PR current controller circuit was added to the single phase five-level inverter circuit with $60 \mathrm{~A}$ reference current. The $K_{p}$ and $K_{r}$ gain was tuned to reduce the THD to less than 5\%. Lastly, adjustments were made to the PR current controller to reduce the THD at the 3rd, 5th, and 7th harmonic orders. The THD of the 3rd harmonic order was reduced from $0.45 \%$ to $0.1 \%$ while the 5 th and 7 th harmonic orders were reduced from $0.6 \%$ and $0.43 \%$ to $0.25 \%$ and $0.4 \%$ respectively.

\section{ACKNOWLEDGEMENTS}

The authors would like to acknowledge Universiti Tun Hussein Onn Malaysia (UTHM), Batu Pahat, Johor, Malaysia for the financial support of this paper publication.

\section{REFERENCES}

[1] P. V. Kumar, et al., "Single Phase Cascaded Multilevel Inverter using Multicarrier PWM Technique," Journal of Engineering and Applied Sciences, vol. 8, pp. 796-799, 2013.

[2] K. S. Reddy and Ch. V. Kumar, "Implementation of a single-phase Multilevel Inverter with Battery balancing," International Journal of Electrical and Electronic Engineering, vol. 1, pp. 35-39, 2014.

[3] E. Beser, et al., "Design and Application of a Single Phase Multilevel Inverter Suitable for using as a Voltage Harmonic Source," Journal of Power Electronics, vol. 10, pp. 138-45, 2010. 
[4] W. S. Oh, et al., "Three phase three-level PWM switched voltage source inverter with zero neutral point potential," IEEE Trans. on Power Electronics, vol. 21 pp. 1320- 1327, 2006.

[5] B. M. Veena and M. T. Triveni, "Hardware Implementation of 5 Level Inverter Using Microcontroller," International Journal of Advanced Research Electrical, Electronics and Instrumentation Engineering, vol. 5, no. 1, pp. 175-182, 2016.

[6] P. V. V. R. Rao, et al., "Hybrid 5-level inverter fed induction motor drive," World Journal of Modelling and Simulation, vol. 10, no. 3, pp. 224-230, 2014.

[7] B. Ismail, et al., "Selective Harmonic Elimination of Five-level Cascaded Inverter Using Particle Swarm Optimization," International Journal of Engineering and Technology (IJET), vol. 5, no. 6, pp. 5220-5232, 2014.

[8] P. Iraianbu and M. Sivakumar, "Single DC Source Based Cascaded H-Bridge 5- Level Inverter," International Journal of Innovative Research Science, Engineering and Technology, vol. 3, no. 1, pp. 995- 1000, 2014.

[9] B. C. Vinayaka and S. N. Prasad, "Modeling and Design of Five Level Cascaded H-Bridge Multilevel Inverter with DC/DC Boost Converter," International Journal of Engineering Research and Applications, vol. 4, no. 6, pp. 50- 55, 2014.

[10] M. S. Sivagamasundari and P. M. Mary, "Sinusoidal PWM Based Cascaded H-Bridge Five Level Inverter Using Fuzzy Logic Controller,” Journal of Applied Sciences, vol. 14, pp. 3486-3492, 2014.

[11] M. V. Kumar and B. Naresh, "A Novel Single Phase Eleven-Level Grid- Connected Transformerless Converter Topology for PV Systems," International Journal of Science and Research (IJSR), vol. 4, no. 9, pp. 375-380, 2015.

[12] R. An, et al., "A Single phase Five level Inverter for Grid Connected Photovoltaic System by employing PID Controller," African Journal of Scientific Research, vol. 6, no. 1, pp. 306-315, 2011.

[13] S. Yogesh, et al., "Five-Level Full-Bridge Single-Phase Grid Connected Converter for Renewable Distributed Systems," International Journal of Advanced Research Electrical, Electronics and Instrumentation Engineering, vol. 3, no. 8, pp. 11327-11333, 2014.

[14] M. P. Kumar and A. S. H. Babu, "A Five Level Inverter for Grid Connected PV System Employing Fuzzy Controller," International Journal of Modern Engineering Research (IJMER), vol. 2, no. 5, pp. 3730-3735, 2012.

[15] G. Balasundaram and S. Arumugam, "Implementation of Five Level Inverter Considering PV System Using MPPT Technique," ARPN Journal of Engineering and Applied Sciences, vol. 10, no. 4, pp. 1552- 1557, 2015.

[16] A. B. Abdelkader, et al., "A comparative study and experimental validation on single phase series active power filter control strategies using pi, flc and sliding mode controllers," International Journal of Power Electronics and Drive Systems (IJPEDS), vol. 10, no. 2, 2019.

[17] P. R. Chandran, et al., "A Multisource Five Level Inverter using an Improved PWM Scheme," International Journal of Science and Research (IJSR), vol. 2, no. 6, pp. 279-282, 2013.

[18] J. M. Shen, et al., "Five-Level Inverter for Renewable Power Generation System," IEEE Trans. on Energy Conversion, vol. 28, no. 2, pp. 257-266, 2013.

[19] Kazmierczuk, et al., "A new phasecontrolled parallel resonant converter," IEEE Trans. On Industrial Electronics, vol. 40, pp. 542-552, 1993.

[20] Babu, Golturu Suresh. "Studies Related to the Operation of Solid Rotor Alternator," Jawaharlal Nehru Technological University, Hyderabad 2013, Shodhganga. Web, 2014.

[21] M. A. Kamarposhti, "Power Quality Compensation in Distribution System based on Instantaneous Power Theory and Recursive Fuzzy Proportional-Integral Controller," International Journal of Electrical and Computer Engineering, vol. 8, no. 1, 2018.

[22] D. Zammit, et al., "Design of PR current control with selective harmonic compensators using Matlab," Journal of Electrical System and Information Technology, vol. 4, no. 3, pp.347-358, 2017.

[23] A. S. Subhadra, et al., "Islanding Detection in a Distribution System with Modified DG Interface Controller," International Journal of Applied Power Engineering (IJAPE), vol. 6, no. 3, 2017.

[24] R. Ortega, et al., "Control techniques for reduction of the total harmonic distortion in voltage applied to a singlephase inverter with nonlinear loads: Review," Renewable and Sustainable Energy Reviews, vol. 16, no. 3, pp.1754-1761, 2012.

[25] "IEEE Recommended Practice for Utility Interface of Photovoltaic (PV) Systems," IEEE Standard 929-2000, 2000. 